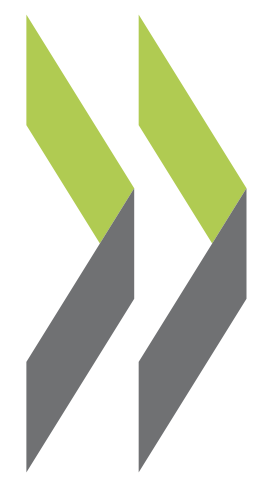

OECD Economics Department Working Papers No. 1252

Russia: Progress

in Structural Reform

and Framework Conditions

Yana Vaziakova 2011-13 
Organisation de Coopération et de Développement Économiques

Organisation for Economic Co-operation and Development

03-Aug-2015

ECONOMICS DEPARTMENT

English - Or. English

RUSSIA: PROGRESS IN STRUCTURAL REFORM AND FRAMEWORK CONDITIONS 2011-13

ECONOMICS DEPARTMENT WORKING PAPERS No. 1252

By Yana Vaziakova

OECD Working Papers should not be reported as representing the official views of the OECD or of its member countries. The opinions expressed and arguments employed are those of the author(s)

Authorised for publication by Robert Ford, Deputy Director, Country Studies Branch, Economics Department.

All Economics Department Working Papers are available at www.oecd.org/eco/workingpapers

JT03380662

Complete document available on OLIS in its original format

This document and any map included herein are without prejudice to the status of or sovereignty over any territory, to the delimitation of international frontiers and boundaries and to the name of any territory, city or area. 
OECD Working Papers should not be reported as representing the official views of the OECD or of its member countries. The opinions expressed and arguments employed are those of the author(s).

Working Papers describe preliminary results or research in progress by the author(s) and are published to stimulate discussion on a broad range of issues on which the OECD works.

Comments on Working Papers are welcomed, and may be sent to OECD Economics Department, 2 rue André Pascal, 75775 Paris Cedex 16, France, or by e-mail to eco.contact@oecd.org.

All Economics Department Working Papers are available at www.oecd.org/eco/workingpapers. 


\section{ABSTRACT/RÉSUMÉ \\ Russia: Progress in Structural Reform and Framework Conditions 2011-13}

Since 1995 when OECD began conducting Economic Surveys of the Russian Federation many policy recommendations relating to structural reform and framework conditions have been made. This paper is an update of an earlier paper that described actions taken up to October 2011 (Vaziakova et al., 2011). It expands the Annex A.1 of the 2013 OECD Economic Survey of the Russian Federation and provides a summary table of the policies implemented.

This Working Paper relates to the 2014 Economic Survey of the Russian Federation www.oecd.org/eco/surveys/economic-survey-russian-federation.htm

JEL classification: E5; E62; F13; H1; H2; H82; H83; I18; I2; J2; J3; K20; K21; L1; L3; L4; L5; L9; Q1; P3

Keywords: Russia, structural reform, framework conditions, business environment, public governance, labour markets, social policy, health, agriculture, innovation, environment, energy efficiency, banking regulation, energy sectors, fiscal policy, monetary policy

**************

\section{Russie : Progrès des réformes structurelles et des conditions-cadres 2011-13}

Depuis 1995, date à laquelle l'OCDE a commencé à mener des Études économiques-de la Fédération de Russie, un grand nombre de recommandations politiques relatives aux réformes structurelles et aux conditions-cadres ont été mises en œuvre en Russie. Ce document est une mise à jour d'un document de travail antérieur qui décrit les mesures prises jusqu'en Octobre 2011 (Vaziakova et al., 2011). Il élargit l'annexe 1.A1 de l'Étude économique de la Fédération de Russie 2013 et fournit un tableau récapitulatif des politiques adoptées.

Ce document de travail se rapporte à l'Étude économique de l'OCDE 2014 sur la Fédération de Russie www.oecd.org/fr/eco/etudes/etude-economique-russie.htm.

Classification JEL : E5; E62; F13; H1; H2; H82; H83; I18; I2; J2; J3; K20; K21; L1; L3; L4; L5; L9; Q1; P3

Mots clés : Russie, réforme structurelle, conditions-cadre, climat des affaires, gouvernance publique, marché du travail, politique sociale, santé, agriculture, innovation, environnement, efficacité énergétique, réglementation bancaire, secteurs de l'énergie, politique budgétaire, politique monétaire 
$\mathrm{ECO} / \mathrm{WKP}(2015) 70$

\section{TABLE OF CONTENTS}

RUSSIA: PROGRESS IN STRUCTURAL REFORM AND FRAMEWORK CONDITIONS 2011-13......5

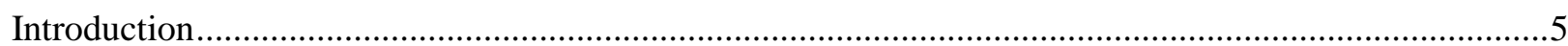

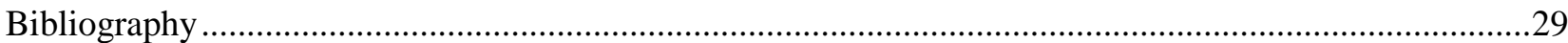

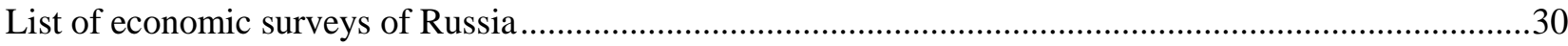


ECO/WKP(2015)70

\title{
RUSSIA: PROGRESS IN STRUCTURAL REFORM AND FRAMEWORK CONDITIONS 2011-13
}

\author{
By Yana Vaziakova ${ }^{1}$
}

\section{Introduction}

The OECD began conducting Economic Surveys of the Russian Federation in 1995. The latest 2013 Economic Survey is the ninth in the series, the most for a non-member country. This background paper by the Secretariat describes actions in relation to recommendations made in all past Economic Surveys taken since the 2011 Economic Survey. The cut-off date for actions is January 2014, thereby not considering sanction or countersanction measures in the wake of the Ukraine conflict. An earlier draft of this paper was discussed by the Economic and Development Review Committee in October 2011. The paper updates an earlier paper that described actions taken up to October 2011 (Vaziakova et al., 2011) and complements Annex A.1 in the 2013 Economic Survey, which provides the synthetic assessment of implementation without describing underlying actions. The annex indicated that a good deal of progress had been made: $4 \%$ of recommendations had been substantially implemented and substantial progress had been made in implementing $29 \%$ of recommendations. In $44 \%$ cases some implementation progress had been achieved. However, progress had been mixed for $3 \%$ recommendations, and no significant action had yet been taken in response to $20 \%$ recommendations.

The assessment of the implementation progress has been carried out by the author. Some of the background information was provided by the Russian authorities, but the bulk was collected independently. In a few cases little if any information could be ascertained, while in others there was more information than could be briefly summarised in this format and the table should therefore not be taken as comprehensive and definitive.

This paper is without prejudice to the recommendations made as a result of reviews by various OECD Committees for the purposes of OECD accession.

1. Yana Vaziakova is a consultant in the Economics Department of the OECD. The author would like to thank the Russian authorities, as well as Andrew Dean, Bob Ford, Andreas Wörgötter, Lilas Demmou, Artur Radziwill, other members of the OECD Secretariat and members of the Economic and Development Review Committee for valuable comments and discussions. 


\section{Recommendations in past Surveys (Survey year)}

Actions taken since October 2011

\section{Business environment}

\subsection{Business regulation}

Continue cutting red tape and increasing the transparency and accountability of the public administration. $(2009,2011)$

The number of one-stop shops is increasing. In many regions one-stop shops have their websites and in some of them there is a possibility for online monitoring of centres workload. "The Concept of administrative barriers reduction and improvement of access to public services for 2011-2013" approved in June 2011 was implemented to optimise the functioning mechanisms of the executive and self-governing authorities.

Reform of inter-agency cooperation in the sphere of state registration simplified and accelerated the procedure of registration: most of the documents received by registration authority are directly coming from relevant departments in electronic form and not from the applicant.

Individual entrepreneurs can submit documents for the state registration in electronic form on the special website www.nalog.ru starting from 2012.

Reduce licencing and other formal regulatory burdens to reduce bureaucrats' opportunities to extract bribes from private-sector firms. (2009)

Federal Law "On Licensing" entered in force in November 2011. It streamlined the licensing system in Russia and excluded the possibility to apply different legal rules to licensing procedures.

The Law defined an exhaustive list of works and services which are considered to be integral part of licensed activity. It significantly reduced the list of activities that need a license (from 82 to 49), whereas number of activities requiring licensing prescribed by other federal laws was reduced to 11 . In many sectors the Law introduced indefinite duration of licence.

Since 1 July 2012 statements and documents for obtaining, renewal, extension of the license can be sent to the licensing authority in electronic form, with electronic signature.

Introduce a "deemed clearance" regime under which licences are issued automatically if the licencing office does not act by the end of the statutory response period. $(2009,2011)$

Ensure that legislative or regulatory changes are preceded by sufficient consultation with affected firms, and provide for adequate transition periods to allow business to adjust. (2011)
The Federal Law "On Licensing" introduced in November 2011 requires that licencing authority should make the decision about granting a licence within forty-five working days from the date of reception of the application. However, the Law did not introduce "deemed clearance" regime.

The Regulatory Impact Assessment procedure requires a period of consultation with key stakeholders. Currently, business community is actively involved in the development of so called "road maps" that are aimed to improve state regulation as well as in the control of "road maps" fulfilment. 


\section{Recommendations in past Surveys} (Survey year)

Systematically carry out Regulatory Impact Analysis to assess the costs and benefits of all significant new regulatory proposals. $(2009,2011)$
Promote and maintain support organisations where entrepreneurs can easily obtain information concerning their various rights and obligations, consulting support, and the ability to lobby their collective interests. (2002)

\section{Actions taken since October 2011}

Since the introduction of Regulatory Impact Assessment (RIA) all government draft acts dealing with regulation are routinely sent to the RIA department of the Ministry of Economic Development (MED), which has already performed more than 1800 assessments $35 \%$ of which had problems requiring changes of the law.

Since 1 July 2013 RIA is held at the same time as the development of draft acts by the regulators. Draft regulations, RIA conclusions and information about the public consultation with key stakeholders are available on a single portal: http://regulation.gov.ru.

RIA is now extended to customs and tax regulations and soon competition acts and Customs Union laws. From 1 January 2014 RIA will be conducted at the regional level (a number of regions are already participating in pilot RIA) and municipal level from 2015.

In 2012 the former head of the non-governmental organisation Delovaya Rossia (Business Russia), was appointed to the newly created position of business ombudsman, who is supposed to protect businesses from administrative and legal abuse. Law on creation of business ombudsmen positions in regions was signed in May 2013 and should come into force in 2014. Already more than 30 regional ombudsmen are working on a voluntary basis. For the moment the main initiative of business ombudsman was to conduct the amnesty for businessmen convicted for the first time for lesser economic crimes. Main business organisations, such as Public Organisation of Small and Medium Enterprises "OPORA Russia", Russian Union of Industrialists and Entrepreneurs and Delovaya Rossia are now actively involved in the development of so called "road maps" aimed at improvement of state regulation and are in the control of "road maps" fulfilment.

\subsection{Trade and foreign investment regimes}

Following approval by the WTO Ministerial Conference, quickly ratify the WTO accession protocol and implement the accession package. (2011)

Reduce both the average and the dispersion of tarif rates, with the medium-term aim of achieving a low uniform rate. (2011)
After formal approval of Accession Package in December 2011, Russia was invited to become 156th WTO member on 22 August 2012. A day before President signed Federal Law "On ratification of Protocol on accession of the Russian Federation to the Marrakesh Agreement on Establishing WTO" that also reflected most of the provisions of the accession package defining the first step to make trade regime in Russia more opened and providing more integration in the world economy.

Currently, Russia has adjusted its tariffs according to the WTO agreement. After the phase-in period, Russia's average bound tariff will be reduced from $10 \%$ to $7.8 \%$. The average tariff will be reduced from $13.2 \%$ to $10.8 \%$ for agriculture products and from $9.5 \%$ to $7.3 \%$ for manufactured goods. The second phase of import duties reduction in fulfilment of the commitments made by the Russian Federation upon accession to the WTO is implemented at the level of the Customs Union. 


\section{Recommendations in past Surveys (Survey year)}

Unwind all restrictive trade measures adopted during the global economic crisis. (2011)

Consider introducing provisions to encourage
regulators to use internationally harmonised
standards and certification procedures wherever
possible and appropriate and avoid unnecessary
trade restrictiveness. (2009)

Develop transport infrastructure as a measure to aid in the elimination of barriers to intraregional trade. (2009)

Increase the openness and predictability of the
foreign investment regime. Review the list of strategic
sectors. (2009)

\section{Actions taken since October 2011}

By joining the WTO, Russia committed to adhere to multilateral rules that ban the arbitrary use of protectionist and discriminatory trade-distorting practices. However, some potentially protectionist measures were recently introduced by the government, including a recycling fee on imported vehicles and food-safety related restrictions on certain agricultural and food products.

Following WTO accession, Russia's sanitary and phytosanitary (SPS) policies need to comply with the requirements of the WTO SPS Agreement, but Russia's SPS measures continues to be often assessed as having negative impact on trade. Russian Information Centre on Standardization, Certification and Overcoming of Technical Barriers to Trade established an enquiry point to cover issues related to TBT and SPS Agreements.

Ministry of Transport developed Draft Transport Strategy of the Russian Federation until 2030. For example plan of Russian Railways (RZD) includes construction of new freight line between Moscow, Bratislava and Vienna as well as connecting Trans-Siberian and Trans-Korean railways. Another announced plan is construction of a high-speed rail line between Moscow and Kazan, an outer ring road around Moscow and upgrading the Trans-Siberian rail lines between Moscow and Vladivostok. The Strategy is also planning to create logistics centres in busy sea ports to develop trade with Japan, Republic of Korea and other countries of AsiaPacific region.

Currently the Russian Federation has concluded intergovernmental agreements on the promotion and reciprocal protection of investments with 75 countries. These agreements provide international standards of protection of investment as well as rights and interests of foreign investors in Russia and Russian - abroad.

Russian Direct Investment Fund was established in 2011 to attract foreign investments and secure co-investments. Since 2011 partnerships with financial institutions in 6 countries were created with a total amount of investments of about USD 11 billion and expected foreign co-financing of USD 25-30 billion.

At the moment Duma is discussing simplification procedures for foreign investors who want to acquire a significant stake in a sector deemed as strategic.

Agency for Strategic Initiatives (ASI) road maps are also aiming to improve the investment climate in critical areas, such as customs, construction and public procurement, at the federal and regional level. 


\section{Recommendations in past Surveys (Survey year)}

Ensure a level playing field between domestic and foreign investors as regards government procurement, access to subsidies, law enforcement and dispute resolution. (2011)

Co-ordinate federal and regional regulation to minimise burdens for foreign investors and assist the regions to disseminate best practice on attracting foreign investment. (2011)

Lower other FDI barriers. (2009)

\section{Actions taken since October 2011}

Federal Law No. 44-FZ "On the contract system in the procurement of goods, works and services for state and municipal needs", which was adopted in 2013, effective as of 1 January 2014, defines equally the purchase of foreign and national goods and service in the cases stipulated by international treaties of the Russian Federation. New Law also contains a block of rules that grant preferences to domestic producers. Currently, customers have the right to restrict the participation of foreign producers only on grounds of national security, whereas the new Law gives the government the right to impose restrictions on the purchase of imported goods and services not only for safety reasons, but also to stimulate the domestic economy.

Agency for Strategic Initiatives is currently implementing Regional Investment Standard on the basis of the best 15 regional practices that are focused on business climate improvement and increase of regions attractiveness for foreign investors. In September 2013 prime minister ordered to establish Russian agency for attracting investments to the regions that should become one-stop shop for foreign investors who have projects starting from USD 5 million. In autumn $2013 \mathrm{ASI}$ is planning to launch a portal dedicated to investment climate situation in regions where every region that implemented these standards could present its opportunities and make investment proposals adjusted to its regional aspects.

Russian Direct Investment Fund (RDIF) operating since 2011 was set up to attract foreign investments in the leading companies in the growing sectors of Russian economy. Reserved capital of RDIF is USD 10 billion. In all transactions RDIF appears as co-investor together with the world's largest institutional investors - private equity funds, sovereign funds, leading industry companies. Currently, RDIF is working on 52 projects in energy, energy-saving, telecommunications, medicine and other fields for an overall amount of USD 11 billion and the expected foreign investments amount of USD 25-30 billion.

\subsection{Competition policy}

Introduce an overarching competition policy in order to bring the issue of competition to centre stage and spread a competition ethos through different levels of government. Introduce a policy to ensure that all levels of government and economic regulatory agencies take the competition dimension into account when formulating policy. (2009)
The government order No. 2579-r of 28 December 2012 approved the road map "Development of competition and improvement of antimonopoly policy" that contains both system-wide and sectoral priorities to promote competition in the Russian Federation in 2013-15: introduction of competition promotion as a task shared across all government institutions, reduction of the share of public sector in the economy, introduction of best practices in the development of competition in the Russian regions, development of competition in infrastructure sectors, including the sphere of natural monopolies, development of competition in procurement, facilitation of business activity in the antimonopoly regulation and improving consumer protection. 


\section{Recommendations in past Surveys (Survey year)}

Apply competition law without exemptions, including for public corporations. (2009)

a programme targeted at reducing violations of antitrust laws by federal and local government. (2009)

\section{Actions taken since October 2011}

Article 3 of the Federal Law No. 135-FZ "On Protection of Competition" applies to relationships that are associated with the protection of competition, including the prevention and restriction of monopolistic activity and unfair competition, and in which Russian and foreign legal entities, organisations, federal bodies of executive power, bodies of state power of subjects of the Russian Federation, local authorities, other bodies carrying out the functions of the bodies or organisations as well as state funds, the Central Bank and individuals, including sole proprietors. Thus, the provisions of the Competition Law apply to all actions aimed at restricting competition without exceptions.

Code of Administrative Offences provides the liability for government officials who have committed a violation of the antimonopoly legislation in the form of a fine, and dismissal in the case of a repeat violation. Currently, work is underway to amend the Administrative Code, according to which the repeated violation of antimonopoly legislation will entail direct public official dismissal without substitution of punishment by a penalty.

Existing provisions of the Law on Protection of Competition fully allow the competition authority to inspect compliance with the antimonopoly legislation by commercial, non-profit organizations, federal bodies of executive power, bodies of state power in subjects of the Russian Federation, local authorities as well as state extra-budgetary funds and individuals. Competition authority also has the right to receive from them the necessary documents and information. This authority can as well apply to the bodies, engaged in the operational-search activity, to conduct search operations in order to identify violations in the area of antimonopoly laws. The Law provides for the right of "dawn raids", i.e. checks without notice of audited entities for the purpose of identifying anti-competitive agreements, including cartels and anti-competitive agreements, members of which are the authorities.

In network sectors, continue separating the These issues are supposed to be resolved in the framework competitive and monopoly market segments and eliminate barriers to entry. (2009)

Develop the capacity and strengthen the hands of the sectoral regulators. (2009) of implementation of the road map "Development of competition and improvement of antimonopoly policy" approved by the government in December 2012.

The roadmap on Competition provides the consolidation of executive power functions (sectoral regulators: Ministry of Energy, Federal Tariff Service and Ministry of Economic Development) to promote competition and establish appropriate Key Performance Indicators. What is more, roadmap foresees adoption the Government act that will set the direction of the competition development in the infrastructure sectors as the electricity, postal services, telecommunications, railways, and gas markets, services in ports and airports, pipelines. Implementation in these areas will be as well done by sectoral regulators. 


\section{Recommendations in past Surveys (Survey year)}

Develop a clear and economically sound interpretation of abuse of dominance and coordination to address the excessively broad interpretation of provisions, which creates significant uncertainty for businesses. (2011)

\section{Actions taken since October 2011}

It is also planned to adjust a ban on abuse of dominance by applying the relevant legal prohibition only in cases where the abuse of monopoly power had or may have an adverse effect on competition, could violate the rights and legitimate interests of entrepreneurs, i.e. have negative effect on trade or offend the interests of some consumers.

Actions restricting competition in the area of establishment of criteria were completely separated from the anti-competitive agreements. It helped to avoid confusion in law enforcement and, therefore, uncertainty for companies and unnecessary regulatory risks.

The third antimonopoly package also significantly refined the concept of economic activity coordination, i.e. coordination of actions of economic entities by a third person who does not belong to the same group and not involved in the commodity market where the coordination of actions takes place.

Ensure that competition law is not used as a means to control inflation or to adjust prices of specific goods or services. (2011)
Federal Antimonopoly Service (FAS) of Russia prepared draft Federal Law "On Amendments to the Federal Law "On Protection of Competition" that is supposed to establish non-discriminatory rules for the access to goods produced and (or) implemented by economic entity occupying a dominant position and not being a natural monopoly. Draft law also forbids prevention, restriction or elimination of competition and (or) infringement of other businesses interests by an economic entity occupying dominant position in the market.

Eliminate all remaining subsidies to large firms introduced or expanded during the global crisis. Subsidies level continues falling slowly. (2011)

\subsection{State role in the economy}

Implement and go beyond the privatisation programme for 2011-13, with a view to giving up government control of enterprises in sectors where competition is viable, while ensuring that privatisation is well managed (2011)

Since 2010 number of state stakes in unitary enterprises halved twice down whereas the number of stakes in joint stock companies decreased from 3000 to 2300 . The biggest transaction was the sale of $7.6 \%$ of Sberbank shares. It brought about $80 \%$ of total government earning from privatisation in 2012 , which was much lower than was initially planned. Moreover, two recent big acquisition deals (Rosneft purchased $100 \%$ of privately owned TNK-BP and VTB bank acquired a majority share in the Bank of Moscow) even increased public share in the economy.

The Privatisation Plan for 2014-16 published in July 2013 is less ambitious than its previous version (notably, it excludes full privatisation of VTB) but still aims at the full privatisation of Rosspirtprom, United Grain Company, RUSNANO and Rostelecom, as well as the Sheremetyevo and Vnukovo airports. It is also planned to reduce state participation in the Aeroflot, Transneft, Uralvagonzavod, RusHydro and VTB, that should bring about RUB 180 billion in 2014 .

Reduce the list of firms for which privatisation requires the approval of the President. (2009) 


\section{Recommendations in past Surveys (Survey year)}

Transparently unbundle the commercial and noncommercial roles of state-owned enterprises, with the latter transferred back to the relevant line ministry and with any remaining non-commercial obligations and responsibilities of the enterprise for public policy purposes clearly mandated by laws or regulations. (2011)

Eliminate the use of golden shares and disclose shareholder agreements and capital structures that allow the government to exercise control over a firm disproportionate to its equity stake. (2009)

Increase the independence and accountability of government representatives and accelerating appointments of independent and accountable directors on SOE Boards. (2009)

Improve standards of transparency and disclosure in SOEs. Eliminate all exemptions, explicit or implicit, for state corporations from various laws, and make them subject to the standard accounting and reporting principles. (2009)

\section{Actions taken since October 2011}

Current actions of authorities focus on addressing the problem by increasing the number of independent directors in public enterprises. Introduction of special committees on the selection of directors and implementation of performancerelated remuneration strengthened the independence and transparency of SOE management. Authorities consider improving the quality of governance in SOEs by obliging them to increase the level of their stock exchange listing. For example Central Bank of Russia (CBR) replaced the representatives from the $\mathrm{CBR}$ and the government with independent members. As for 31 May 2013 there were 8 independent representatives out of 17 members of the Supervisory Board of Sberbank of Russia (comparing with 3 out of 16 between 2000 and 2005).

No known actions taken since October 2011.

2011 President Order to replace civil servants by independent directors and professional attorneys until 1 September 2015 is being implemented. At the end of 2012 public companies had 1512 professional and 601 independent directors (including the biggest SOEs such as RZD, VTB, Rosneft, Gazprom). The process of selection is organised by the Federal Property Management Agency (Rosimuschestvo) together with Agency for Strategic Initiatives.

Rosimuschestvo encourages public companies to improve standards of transparency and disclosure of information (i.e. number of independent directors or existence of auditing committee) that will in its turn increase the listing level of these companies at the Moscow Stock Exchange.

\section{Public governance}

\subsection{Public administration and anti-corruption}

Pursue civil service reforms to improve the fairness, transparency and efficiency with which remaining regulations are administered. (2009)

Implement administrative reform to mitigate the potential for corruption by minimising uncertainty and subjective decision making within the government administration. (2009)
According to the federal program on Reforming and Developing Civil Service in 2009-13 monitoring of the results of this programme should be done annually. The performance evaluation reports are sent to the program coordinator in the Ministry of Labour for control.

Government Commission on Administrative Reform regularly adopts anti-corruption plans for federal executive bodies in line with National Anti-Corruption Strategy and the National Plan to Combat Corruption. Accordingly federal executive bodies accept departmental plans and implement anticorruption measures.

Involvement of public officials in the discussion and development of regulations on anti-corruption is promoted; information concerning corruption and conflict of interest risks and prevention is widely available.

Anti-corruption monitoring is conducted on the regular basis. Efficiency of anti-corruption measures is assessed using both internal indicators and online citizens' surveys.

According to the General Prosecutor Office the number of corruption cases in Russia in 2012 amounted at 49 513, a $22.5 \%$ increase relative to the previous year. 
Recommendations in past Surveys (Survey year)

Strengthen Russia's anti-corruption legislation, bringing it into line with international standards. (2006)

To prevent misconduct in the public procurement system, identify risks to integrity for particular positions, activities and projects and set up specific mechanisms to minimise those risks. (2011)

\section{Actions taken since October 2011}

According to the Federal Law No. 3-FZ of 1 February 2012, Russia joined OECD Anti-Bribery Convention. The Phase 1 evaluation report adopted by the OECD Working Group in March 2012 identified a number of challenges, especially a need to explicitly and clearly ensure the criminalisation for the "offer" and "promise" of a bribe, and to ensure that giving bribery to a third-party is also legally covered. Discussion on Phase 2 report took place in Paris early October 2013 suggested that Russia made a lot of progress in implementation of Convention principles, but also urged that legislation and law enforcement to be strengthened.

Federal Law No. 44-FZ of 5 April 2013 "On the contract system in the procurement of goods, works and services for state and municipal needs" that will enter in force on 1 January 2014 aims to increase transparency and openness at all stages of the procurement process. This law is planning to create single information system that will monitor all the contract information provided and will contain procurement plans and schedules. This system will provide full document flow between all the parties of procurement system. The work is planned to be finished by 2015. Some types of purchases would require mandatory public discussion that can result in the modification or even cancellation of procurement.

Presidential Decree ordered a catalogue of government positions associated with corruption risks. Several awareness campaigns directed at civil servants were launched. Compulsory disclosure of income, expenditures, assets and property by public officials, their spouses and children was strengthened. A separate law obliges senior officials and close family members to close foreign bank accounts and repatriate financial assets abroad by September 2013.

Impose an effective firewall between public and private professional activities to avoid conflicts of interest. (2009)

All public institutions and state owned enterprises are obliged to create a commission to consider cases of violation of the Code of Ethics provisions and conflict of interest regulations. The monitoring of corruption risk has been strengthened, notably through the introduction of a catalogue of government positions associated with high corruption risks. These changes have been accompanied by intensive information campaigns for civil servants.

Adopt measures to strengthen protection for Creation of legislative acts protecting whistleblowers is under whistleblowers. (2011) discussion. In the Presidential Decree No. 309 of 2 April 2013 "On measures to implement certain provisions of the Federal Law "On Combating Corruption" some procedural measures protecting whistleblowers have been introduced. Whistleblowers could be held liable to disciplinary action only after the respective case is addressed at a meeting of the committees responsible for compliance with official conduct requirements and settlement of conflicts of interest. They are also entitled to free legal assistance if facing any kind of prosecution. 


\section{Recommendations in past Surveys (Survey year)}

Increase substantially the pay for important civil servants and establish a strong threat of immediate removal in the event of violations. (2002)

Expand the range of opportunities for using ICT in interactions between officials and ordinary citizens or businesses, especially in fields such as licencing or procurement. (2006)

\section{Actions taken since October 2011}

At a meeting of the Commission under the President for Civil Service and Senior Executives reserve on 29 May 2013 the proposal for phased changes of existing pay structure for civil servants was introduced. It is planned to increase ratio of guaranteed and incentive payments to 60 and $40 \%$ correspondingly, until 2018 (at the moment the ratio is $90 \%$ to $10 \%)$.

According to Rosstat the average monthly salary of civil servants in the federal government agencies in 2012 was RUB 72.1 thousand that represent $115.3 \%$ of 2011 level.

Starting from 1 October 2013 wages were increased to all high-level officials by about $50 \%$.

An important element of creating e-government infrastructure is a national platform of distributed data processing (NPROD) - a set of information system for the provision of a number of services via the Internet. Information certification centre, that is already implemented, provided the possibility to submit documents in electronic form signed by electronic signature and receive a number of public services via the Internet.

New Law on Procurement intends creation of single information system to make procurement process more transparent.

According to Government Act No. 851 of 25 August 2012 "On the Procedure for disclosing information on the preparation of regulations and public debate" all federal executive agencies are required to place on the portal regulation.gov.ru by 15 April 2013 information on the preparation of regulatory legal acts, as well as to organize its public discussions. Single portal of information disclosure of draft regulations and the results of their public discussion are organised to increase transparency of the federal bodies of executive power and exercise the constitutional right of citizens, associations and organizations to be involved in the management of state affairs.

\subsection{Judicial system and law enforcement}

Strengthen judicial independence, with better training and pay for judges. (2011)

New Federal Program "Development of the Judicial System 2013-2020" includes a number of measures aimed to increase transparency, accessibility and openness of the judicial system. This includes audio-visual recordings of proceedings and broadcasting sessions in the Internet. Presidential Decree of June 2012 increased judicial salaries and provided extra payments dependent on qualification and skills. Monthly fee is introduced, amount of qualifying classes increases from 6 to 10, including the highest qualification category. For example, the fee for the 9th grade is set to $30 \%$ of the salary where as for the highest category to $150 \%$. It is supposed that average salary of arbitration court judges will increase from RUB 132 to RUB 150 thousand, regional courts judges of general jurisdiction - from RUB 115 to RUB 132 thousand and district courts - from RUB 102 to RUB 104 thousand.

Ensure regular rotation of judges among courts to No known actions taken since October 2011. legal decisions. (2011) 


\section{Recommendations in past Surveys Actions taken since October 2011 \\ (Survey year)}

Give tribunal presidents less scope for discretion as regards assignment of judges; case assignments could even be randomised. (2011)

Avoid even the appearance of political interference in No known actions taken since October 2011 law enforcement or court cases. (2011)

Create effective non-judicial mechanisms, including an effective system of administrative redress and an ombudsman or similar institution, for citizens and organisations seeking to defend their interests in conflict with public bureaucracies. (2006)
No known actions taken since October 2011.

Position of business ombudsman, who is supposed to protect businesses from administrative and legal abuse, was introduced in 2012. The same positions in regions will be introduced in 2014 , but at the moment about 30 people are doing the work of regional ombudsmen on a voluntary basis. Most important initiative of business ombudsman since his appointment is conduct the amnesty for businessmen convicted for the first time for lesser economic crimes. By the end of 2013 more than 2000 businessmen already benefited from the amnesty.

Press ahead with reforms aimed at making law- No known actions taken since October 2011. enforcement agencies more transparent and accountable. (2006)

\subsection{Transparency and civil society participation}

Adopt freedom of information legislation, along with other measures to establish a norm of transparency in public bodies. (2006)

According to Government Act No. 852 of 25 August 2012 851 "On the Procedure for disclosing information on the preparation of regulations and public debate", all federal executive agencies by 15 April 2013 are required to place on the portal regulation.gov.ru information on the preparation of regulatory legal acts, as well as organize its public discussions. Single portal of information disclosure of draft regulations and the results of their public discussion is organized to increase transparency of the federal bodies of executive power and exercise the constitutional right of citizens, associations and organisations to be involved in the management of state affairs.

"Concept of open data" developed by the Ministry of Economic Development was approved in December 2012. Open Data sections were created at more than 50 official websites of federal bodies, including information about education, housing, health care and public procurement. As for 15 July 2013 authorities put more than 1000 set of data.

Federal Law "On Amending the Federal Law "On Information, Information Technologies and Protection of Information" that entered in force in July 2013 and Federal Law "On ensuring access to information about the activities of state bodies" further determined policy in the sphere of publication of information in the form open data. 


\section{Recommendations in past Surveys (Survey year)}

Complement top-down anti-corruption measures with reforms favouring political openness, transparency and civil society participation. (2011)

\section{Sectoral policies}

\subsection{Labour markets and social policy}

Equalise pensionable age for men and women and in longevity. (1995, 2009, 2011)

\section{Actions taken since October 2011}

In 2012 the President introduced new minister responsible for the implementation of the principles of open government. Government Commission for the coordination of open government and Expert Council were created in May 2012.

In 2012-13 the government adopted a number of decisions aimed at involving citizens in the decision-making process (creation of drafting regulatory acts disclosure system, reform of the regulatory impact assessment, improvement of community boards, creation procedure and others).

Decree No. 183 of 4 March 2013 introduced a new "Russian Public Initiative" that implements the constitutional right of citizens to participate in the authorities' decision-making process.

According to the National Anti-Corruption Plan 2012-13 Public Chamber developed and submitted for public discussion the draft Federal Law "On the principles of social control in the Russian Federation" that would define the credentials of the institutions of public control over the activities of the federal and regional authorities and local government.

However the recent law on assembly put in place much tighter restrictions on participation in public debate. Another law on "foreign agent" obliged NGOs that are involved in broadly defined political activities and receives financing from abroad to register as a "foreign agent" that has the connotation of spying.

$$
\text { (n) }
$$
gradually raise the pensionable age in line with gains
Undertake reforms directed at providing more
effective, targeted and fiscally sustainable social
protection to vulnerable groups in the population. (2006)
Raise of retirement age has been explicitly ruled out by the current administration. However, long-term Strategy of the pension system development approved at the end of 2012 envisages introduction of mechanisms that encourage citizens to retire later by establishing higher pensions for later retirement. Such mechanisms are included in the set of laws, including Federal Law "On non-contributory pensions" which was signed by the President in 2013.

New version of the Federal Law "On the Principles of Social Services in Russia" defines the level of social aid based on individual needs, determines requirements for the social services standards and establishes a procedure for getting free services for some categories of citizens.

Since 2013 social pensions for some vulnerable groups of population were increased (disabled children, people disabled from childhood) as well as the monthly payments for their parents or caretakers.

Regions introduced a monthly monetary payment for needy families for the birth of the third and next child.

Promote free movement of labour. Relax security of tenure laws and progressively raise controlled rents towards market levels. (1995)
The co-financing of costs associated with moving and recruitment (i.e. partial compensation of 6 months wage) of employees, coming from regions with high labour market tension, was introduced in 2012 and 2013. 


\section{Recommendations in past Surveys (Survey year)}

\subsection{Health}

Strengthen primary care provision and reduce the current over-reliance on tertiary care. (2006)

Adopt payment schemes that encourage more cost-effective therapeutic choices. (2006)

\section{Actions taken since October 2011}

According to Federal Law "On OMS system" in 2011-13 a number of regional programmes of healthcare modernization with a focus on primary health care improvement were implemented. As a part of this program the volume of outpatient care was increased by raising prevention component. This allowed increasing the level of detection of diseases at an early stage which made a positive impact on sickness dynamics.

The Federal Law "On the principles of health protection in Russia" decreed that starting from 2013, the definition and delivery of medical care is regulated by the regime that is uniform for all medical organisations.at the territory of the Russian Federation. These orders are developed according to different profiles, diseases or state. In the orders that were already approved (about 50) an increase of primary health care while decreasing specialized medical care is set up.

Article 80 of the Principles of the state guarantees of free medical care provision includes the ways to pay for health care. According to the current 2012 version of the programme a new more precise list of medical assistance payment was defined(i.e. paying for medical care in outpatient setting; medical care in a hospital; per case of treating a disease; emergency medical care provided outside the health facility; call for emergency medical assistance and others)

While raising public healthcare spending, revise the guaranteed benefits package to bring formal commitments into line with available resources, dropping those guarantees that create perverse incentives or are likely to prove financially unsustainable. (2006)

Government Decree No. 1074 established a list of diseases, conditions and forms of free medical care performing. A comprehensive list of services is available for free: primary health care, specialized care, ambulance services and others. In addition, a list of activities funded directly from the federal budget for the privileged categories of citizens was approved.

Create mechanisms to enable citizens to take effective action, at reasonable cost, if the commitments made in the revised guarantee package are not met. (2006)

Establish a framework for regular, transparent review and revision of the guaranteed package in light of medical, technological and economic change. (2006)
Government established control mechanisms in the health sector, which include: monitoring medical service quality and safety, the state control (supervision) in the field of medicines, carried out in accordance with the laws of the Russian Federation on the circulation of medicines, state control over the circulation of pharmaceuticals; federal state sanitary and

The Law on Compulsory Health Insurance established reimbursement mechanisms of payments for medical care provided to the insured person in the case of the injury to his health. The amount of expenses to pay for the insured person is determined by the health insurance company based on the registry of payments to the medical organisation.

The package of guaranteed free medical care is approved for a period of three years (the next fiscal year and the planning period). The government annually reviews a report on its implementation. The programme can be adjusted according to changes in medical, technical and economic parameters of care. epidemiological surveillance and others. 


\section{Recommendations in past Surveys (Survey year)}

End the "two-channel" budget-insurance system of financing healthcare and ensure that the great bulk of healthcare spending takes place via the OMS system, if necessary by channelling most budgetary resources through OMS funds. (2006)

\section{Actions taken since October 2011}

According to the Law on OMS system (in force from 1 January 2013) payment for medical care in the framework of compulsory health insurance includes mostly all expenditures (except those having investment nature), that is considered to be an important step towards "one-channel" financing.

Since 2013 ambulance services are also funded from OMS. In 2015 it is planned that specialized services, including hightech medical care will be as well funded from compulsory health insurance system. Thus it is planned that in 2015 the transition to the "one-channel" financing will be competed.

Create mechanisms to make it easier for individuals to assess the relative performance of medical insurers and to choose their own insurers. (2006)

According to the Law on OMS system all the necessary information on the services provided, financial results, performance indicators, experience, etc., the health insurance organisation usually put on their official website or publish it in the media. According to the same Law, insured persons have the right to choose health insurance company by filing an application. They also have the right to change health insurance company once per calendar year.

Strengthen the regulatory framework governing the activities of medical insurers in the OMS system, while simultaneously expanding their freedom to compete with one another. It is critical that they be made risk-bearers. (2006)

Encourage pilot projects in the regions with respect to OMS reform, including, where appropriate, experiments involving a single-payer system. (2006)

Increase investment in primary care in order to establish a long term, coordinated effort to strengthen the training of primary care physicians (GPs) and to provide them with practice settings that favour the provision of integrated primary care. (2006)
The Law on OMS system regulates the rights and responsibilities of health insurance organizations providing OMS. The rights and responsibilities of organization are established by comprehensive agreement on financial provision of services and medical service rendering.

In case of non-fulfilment of the agreement on financial security regarding volume, timing, quality and conditions of medical services, insurance company have to pay the territorial fund a penalty.

For non-payment or late payment of medical services provided under the contract insurance company at its own expense shall pay the penalties for medical organization.

For refusal, failure to provide medical service or its inadequate quality medical organization shall pay a fine as it was established by the contract.

Currently, all the regions are completing the transition to one-channel financing in the framework of OMS. OMS Federal Fund is a single-payer who pays territorial fund unified subvention for the implementation of the basic OMS package.

State Programme "Development of Healthcare" is aimed at ensuring availability of medical care and improving the efficiency of medical services. Their volume, type and quality have to correspond to the level of illness and the need of population as well as advanced achievements of science. The Programme consists of 11 subprogrammes, including those on "Prevention of diseases and promotion of healthy lifestyle. Development of primary health care" and "Staff assistance of the healthcare system". The second subprogramme is supposed to carry out training and retraining of medical and pharmaceutical workers, and implement a set of measures to improve accessibility and quality of primary health care to the population.

The programme will be implemented in two phases: the first covers structural changes (2013-15) and the second is focus on the development of innovative capacity in health care (2016-20). 


\section{Recommendations in past Surveys (Survey year)}

Shift away from cost-reimbursement or capacitybased methods of financing healthcare in favour of more efficient methods, such as cost-and-volume contracts. (2006)

Eliminate the inpatient/outpatient distinction in determining eligibility for free medicines and restructure the arrangements governing access to free medicines, emphasising proven efficacy, safety and cost-effectiveness - with particular stress on the added value of new or especially expensive drugs. A tiered system of co-payments may have a role to play here. (2006)

Incremental resources should be devoted to preventive medicine, for example, to the restoration of abandoned or rundown immunisation programmes. (1995)

\subsection{Innovation}

Broaden the opportunities and incentives for universities and institutes to pursue the commercialisation of the results of their research via the creation of technology transfer offices and/or spinoff companies. (2006)

Increase the penalties for Intellectual Property Rights (IPR) violations and reduce the scope for relying on "copycat" patents. (2006)

Shift to greater reliance on project-based rather than institutional financing of state-funded research. (2006)

\section{Actions taken since October 2011}

According the Law on OMS payment for medical care provided by health care organizations is carried out in accordance with the contract on provision and payment for health care under OMS that establishes the amount of health care, payable at OMS expense.

Providing primary health care both as a day hospital and in emergency form, citizens are provided with all the necessary drugs that are included in the list of essential according to the Federal Law "On Circulation of Medicines" as well as medical devices that are provided according to the standards of medical care. In outpatient care free drugs are provided only for individual categories of population receiving aid.

Subprogramme "Prevention of disease and promotion of healthy lifestyles. Development of primary health care" was launched in 2013 under the State Programme "Development of Healthcare" This subprogramme includes implementation of activities aimed at the development of primary prevention of contagious and non-contagious diseases for the period up to 2020 .

New Federal Law "On Education in the Russian Federation" introduced in 2013 a number of amendments including the possibility for educational institutions to create economic partnership to make commercialization of intellectual activity results (IAR) more flexible. Another amendment extends the list of entities that can set up companies for commercialization of IAR with private investors.

Court for Intellectual Property Rights was created at the end of 2011 (Federal Constitutional Law No. 4-FCZ of 6 December 2011. In July 2013 amendments to the Code of Administrative Offences established administrative responsibility for non-admission of the measures that restrict access to the content that distributes information resources in violation of IPR.

At the first step of Innovation Strategy (2011-13) it was planned to further develop competitive funding mechanisms. Grant financing programs are expected to be opened to all qualified researchers with results of previous projects and publications in foreign journals being one of the main selection criteria.

At the end of 2012 Government Order No. 2538 approved the Programme for Fundamental Research for 2013-20. It foresees introduction of competitive financing mechanisms and improvement of financial instruments to support research activities in the country.

In 2014 it is planned to launch a project "1 000 laboratories" that on competitive basis will provide grants to research teams to create or develop the laboratory. Scientists could choose themselves the enterprise or university under the aegis of which the laboratory will be created. 


\section{Recommendations in past Surveys (Survey year)}

Ensure the involvement of the scientific community, the business community and civil society organisations in the determination of state priorities for funding R\&D. (2006)

Introduce mechanisms for performance-based pay and more rapid advancement. (2006)

\section{Actions taken since October 2011}

In 2011 the interdepartmental Committees on the implementation of the Innovation Strategy up to 2020 and on Technological Development were created under the Presidential Council on economic modernization and innovative development.

The Ministry of Economic Development involves different business association for establishing technological platforms and selection of regional innovation clusters. Those technological platforms are then involved in the government policy elaboration and development of educational standards.

The Presidential Decree of 22 December 2012 ordered creation of road maps in priority areas of technological development that are supposed to create supplementary synergy between the executive authorities and interested organizations and businesses.

Ministry of Education developed the draft of Government Decree that will amend government resolution of 8 April 2009 "On the rules of assessing the effectiveness of scientific organizations engaged in research, development, engineering and civil engineering works". It is supposed to provide norms of performance assessment of scientific organizations as well as to compare their performance with those of research organizations in developed countries.

Reduce the number of direct recipients of $R \& D$ funds from the federal budget. (2006)

Restructuring and downsizing the state-owned branch research institutes and design organisation continues. The law consolidating the Russian Academy of Sciences, Academy of Medical Sciences and of Agricultural Sciences was adopted in 2013.

Facilitate information exchange and other contacts As of August 201360 large state-owned companies in key between R\&D organisations and the business community. (2006)

Increase the share of public research funding allocated to universities, while enhancing their financial incentives to strengthen links to other public $R \& D$ organisations and to private businesses. (2006) sectors of Russian economy, that represents about $20 \%$ of GDP, started to implement programs of innovation development (PID). Federal executive authorities organized the annual monitoring of the PID implementation that will provide an assessment of annual targets and key performance indicators achievement.

As of August 201332 technology platforms were created in a number of areas to allow science, government, businesses and consumers to develop a common vision of technological development perspectives as well as create and implement an intensive R\&D programme.

The government selected 25 pilot innovative clusters in 2012 that would be receiving additional federal support. They concentrate great scientific and industrial potential in areas such as pharmaceuticals, information, communication and nuclear technologies, supercomputers and biotechnology.

Government Resolution "On the measures of state support of Russian higher education institutions implementing complex projects on high-tech production" formed the basis for subsidies for the creation of high-tech production with participation of academic institutions as performers of R\&D. Government Resolution "On state support of leading universities to increase their competitiveness among the world's leading research and education centres" that was adopted in March 2013 provided allocation of RUB 9 billion from the budget for 15 leading universities (chosen on competitive basis) in order to increase their competitiveness in the international arena. 


\section{Recommendations in past Surveys (Survey year)}

Ensure that fiscal incentives for private-sector $R \& D$ are simple, universal, and aimed at promoting specific activities rather than supporting particular populations of firms. (2006)

Ensure that except in the cases of start-ups and small firms, such incentives rely on tax breaks rather than subsidies. (2006)

Facilitate the development of private venture capital via reforms aimed at creating a more attractive legislative and tax framework for Venture Capital firms. (2006)

\section{Actions taken since October 2011}

Government Resolutions No. 424 and 426 of 21 May 2013 provide financing on a competitive basis for $R \& D$ enterprises according to defined topics in the framework of science and technology priority areas.

Government Resolutions No. 96 of 6 February 2012 approved changes in R\&D activities list, costs to which according to Article 262 of the Tax Code of the Russian Federation are included in the other expenses with the coefficient 1.5 .

In November 2011 Federal Law "On Investment Partnership" defined the form of collective investment and the Federal Law of 3 December 2011 "On Business Partnerships" introduced a new organizational form that allows stepwise contributions payment, establishes comfortable liability limitations for participants and helps to manage the business. These measures are supposed to significantly enhance Russian jurisdiction competitiveness in comparison with foreign countries, in the area of structuring venture capital deals.

In the framework of "innovation lift" a mechanism for the exchange of information among business and other key stakeholders about promising innovative projects was introduced.

In July 2012 Government Resolution extended financial support instruments for innovation activity participants of the Fund for Assistance to Small Innovative Enterprises in Science and Technology.

Ensure that selection procedures for any direct support programmes aimed at start-ups and small firms are highly transparent and rely upon broad expertise involving entrepreneurs, the applied science sector and private investors. (2006)

\subsection{Agriculture}

Businesses applying for grants have to undergo a technical audit and an expert evaluation, after which it will obtain the status of "innovative business".
Create a functioning market in agricultural land. (2006) (2006)
Rationalise state support for the agriculture sector.

The State Programme of Agricultural Development for 2008-12 that was followed by the Programme of agricultural development and regulation of agricultural products, raw materials and food for 2013-20 defines one of the main priorities creation of competitive domestic agricultural market.

Government Resolution No. 717 of 14 July 2012 defined new state programme of agricultural development and regulation of agricultural products, raw materials and food for 2013-20. This programme takes into account the requirements of the current stage of Russia's membership in the WTO. The programme is focused on improving financial sustainability of agriculture, sustainable development of rural areas and increase of the efficiency in agriculture, land and other resources.

Make leasing and equipment markets more State Programme of Agricultural Development for 2008-12 competitive. (2006) provided a range of subsidies for variable inputs and investments, including subsidies for mineral fertilisers, transportation of crop, leasing machinery and livestock and others. 


\section{Recommendations in past Surveys (Survey year)}

\section{Actions taken since October 2011}

\subsection{Banking sector}

Explicitly divide the Russian banking sector into tiers subject to different levels of supervision, to allow scarce resources to be more focused on the larger banks. (2009)
Federal Law of 2 July 2013 extended the list of reasons for the appointment of authorized representatives of the Central Bank of Russia (CBR) to credit institution with assets size exceeding RUB 50 billion and/or the amount of retails deposit exceeding RUB 10 billion.

Central Bank is currently working on definition of regulation and oversight of systemically important domestic credit organisation. In particular, it is planned to develop a method for determining these organisations, define prudential requirements for their activities, include implementation of consolidated supervision procedure as well as the order of their pay systems evaluation.

In order to improve remote control system it is decided to establish a department of control over systemically important credit institutions in the Central Bank of Russia.

Improve the structure of the banking sector by outlining a long-term privatisation strategy for the state-owned banks. (2009)

In September 2012 CBR has sold $7.58 \%$ stake of JSC "Sberbank of Russia", resulting in decrease of state participation in the company from $57.6 \%$ to $50 \%$ plus 1 share. As a result of SPO of VTB Bank in May 2013 the share of Russia's participation in its authorized capital decreased from $75.50 \%$ to $60.93 \%$.

Government Order of 1 July 2013 "Forecast plan of federal property privatization and the main directions of privatization for 2014-2016" foresees reduction of state participation in VTB to $50 \%$ plus 1 share by 2016 . Reduction of state share in VTB Bank capital below $50 \%$ plus one share will be considered and carried out in coordination with the similar process in Sberbank of Russia.

Facilitate and encourage consolidation of the sector, via speedy resolution of failing banks, facilitation of mergers, and higher minimum capital requirements. (2009)

Federal law of 3 December 2011 "On Amending the Federal Law "On Banks and Banking Activity" envisaged the increase of banks own funds minimum amount up to RUB 300 million from 1 January 2015.

The draft law on improving procedures of distressed credit institutions financial recovery was prepared by the Ministry of Finance, Ministry of Economic Development, Ministry of Justice, Bank of Russia and Russian State Corporation in 2013.

Improve the quality of on-site supervision, including via increased resources for staffing and training. (2009)

The Central Bank of Russia decided to set up 8 main departments in federal districts of the Russian Federation. It conducts professional development of its staff, including trainings in the area of supervision and crisis management. Starting from November 2011 official website of the Bank of Russia opened a new section "Career in the Bank of Russia ", which allows quickly and accurately fill existing vacancies on a competitive basis.

Further streamline formal requirements on banks, while strengthening risk assessments. (2009)
CBR is currently working on introduction of Basel II provisions in the area of regulation and control. Federal Law of 2 July 2013 established that the Central Bank of Russia will be defining the order of risk assessment based on intrabank ratings. It will as well determine minimum standard of internal capital adequacy for credit institutions, prepare regulatory framework, and provide a methodology for process supervision of the capital adequacy of credit institutions. 


\section{Recommendations in past Surveys (Survey year)}

Play an active role in international efforts to improve financial regulation. (2009)

\section{Actions taken since October 2011}

Russia participates in the work of Financial Stability Board (FSB) and the Basel Committee on Banking Supervision. Bank of Russia cooperates with the ECB in the areas of monetary policy, financial stability and banking supervision. A large number of bilateral agreements are made with a wide range of foreign central banks and financial regulators. In 2012, the Bank of Russia took part in all major events of G20 "financial track" as well as in the activities of G20 Working Groups. It also actively participated in the preparation of G20 Concept of Russia G20 presidency.

Explore ways of making capital adequacy requirements countercyclical, such as via dynamic provisioning rules, higher capital adequacy requirements in cyclical upswings, and capital requirements that vary across banks according to their contribution to systemic risk. (2009)

Central Bank of Russia is currently working on the implementation of Basel III provisions in the area of introduction of counter-cyclical capital buffer according to the schedule set by the Basel Committee on Banking Supervision. Phased-in implementation is supposed to start in 2014.
In 2013 the Bank of Russia developed internal models for of credit cycle monitoring and prepared a long-term historical data series. CBR began a quarterly assessment of the dynamics of the credit cycle that is needed for macroprudential analysis.

Expand the use of stress testing, including more testing of system-wide shocks affecting counter-party and market risks. (2009)

Since 2012 the Bank of Russia began to conduct stress tests to assess systemic risk in the repo, interbank and swaps markets. Test results are publicly disclosed in the quarterly "Money market survey" These stress tests consider counterparty and market risks.

Seek improved ways of regulating liquidity and responding to shortages for individual banks. Require banks to prepare periodic liquidity assessments for review by the CBR, with the CBR to give liquidity guidance to banks on an individual basis. (2009)

Amend Article 837 of the Civil Code which states that term deposits of households may be withdrawn on demand. (2009)

The Bank of Russia is working on implementation of new international requirements for maintaining a necessary level of liquidity foreseen by the Basel Committee on Banking Supervision reform package (Basel III).

Draft Federal Law "On Amendments to Part II of the Civil Code of the Russian Federation and Certain Legislative Acts and the Annulment of Certain Provisions of Legislative Acts", foresees the introduction new form of bank deposit that does not envisage early withdrawal the deposit or its part. The law is currently under approval with concerned departments where, in particular, the issue of property rights violation prevention will be discussed.

Expand the use of IFRS financial reporting, including for non-banks. (2009)

According to the Federal Law of 27 July 2010, publication of consolidated financial statements prepared in accordance with IFRS is obligatory for credit institutions starting in 2012.

In February 2013 Bank of Russia issued a letter "Methodical Recommendations "On the procedure of drawing up financial statements of credit institutions" that included a sample disclosure of overdue loans, fully compliant with IFRS 7.

Develop a system of personal bankruptcy. (2009)
Draft Federal Law "On Amendments to the Federal Law "On Insolvency (Bankruptcy)" and some legislative acts of the Russian Federation..." was adopted in the first reading 14 November 2012 and is currently being reworked by the State Duma. 


\title{
Recommendations in past Surveys (Survey year)
}

\section{Actions taken since October 2011}

\subsection{Energy Sector}

\author{
3.6.1. Electricity sector
}

Provide for market rules which are transparent, stable No known actions taken since October 2011.

and effectively enforced. (2004)

Reduce the broad discretion for the government in the No known actions taken since October 2011.

field of electricity regulation. (2004)

Provide for a strong, independent electricity regulator. No known actions taken since October 2011. (2004)

Introduce competition into those activities where it is feasible, such as generation and supply. (2004)

A number of reforms included privatisation of the electricity generation of RAO UES, liberalisation of the wholesale market, with the creation of a day-ahead spot market and capacity mechanism, unbundling of generation/supply and network activities, introduction of Regulated Asset Base regulation and the recent launch of an ancillary services market and financial guarantees at the wholesale level.

Set regulated tariffs for transmission and distribution, which are natural monopolies, in such a way as to encourage efficiency and not merely cover costs. (2004)

Russia recently introduced $\mathrm{RAB}$ regulation of electricity transmission and distribution networks. Regulated electricity tariffs reach a share of $40 \%$ and $80 \%$, depending on the region, and have pushed the price of electricity upwards.

According to the Federal Electricity Law, regional tariff authorities can establish regulated tariffs for the amount of green electricity that network companies purchase to compensate their network losses but the law prevents regional tariff authorities from adopting sufficiently long-term tariffs that correspond to the return on renewable energy investments.

Raise average domestic electricity and gas tariffs and reduce cross-subsidisation. (2002)

Regulated tariffs for final household consumers have been gradually increasing towards cost recovery, but remaining cross-subsidisation between industry and households is a barrier to the creation of a competitive retail market. Domestic regulated prices of utilities, including electricity and gas, may be either frozen or increased more slowly than inflation in the next three years.

\subsubsection{Gas sector}

Put an end to the provision of implicit subsidies via prices which are below long-run cost recovery levels. (2004) Raise domestic gas tariffs and reduce cross-subsidisation while making regulation less politicised and unpredictable. (2002)

Regulated tariffs for final household consumers have been gradually increasing towards cost recovery, but remaining cross-subsidisation between industry and households is a barrier to the creation of a competitive retail market. In the wake of the economic slowdown, domestic prices of utilities, including electricity and gas, are to be either frozen or increased more slowly than inflation in the next three years.

Separate regulatory and ownership functions more clearly and reduce the state's ownership of energy sector assets. (2004)

Establish an effective third-party access regime for the sector's infrastructure. (2004)

No known actions taken since October 2011.

About $20 \%$ of Russia's gas production comes from non-Gazprom companies and is being shipped thanks to third party access through the gas transmission system, although there are still problems of transparency, predictability and tariffs.

Provide for a separation of Gazprom's natural monopoly/infrastructure provision functions from its potentially competitive activities. (2004)

Currently Gazprom's share in the domestic market has declined and is about $70 \%$, due to the increase of production and sales by non-Gazprom producers. 


\section{Recommendations in past Surveys (Survey year)}

Achieve a clearer separation of Gazprom's accounts with respect to production, transport and dispatch. Increase transparency in the company's other activities. (2004)

Formulate and implement clear rules and principles governing the allocation and administration of quotas for regulated-price gas. (2004)

Provide for a fair, stable, effective and transparent regulatory framework in which regulatory decisions are taken by an independent, expert regulatory authority rather than a market player. Minimise Gazprom's role as a de facto regulator in the gas sector, particularly as regards the allocation of regulated-price gas and pipeline access. (2004)

\section{Actions taken since October 2011}

No known actions taken since October 2011.

No known actions taken since October 2011.

Non-Gazprom gas producers are increasingly operating in the upstream and supply segment of the market. Federal Tariff System and Anti-monopoly committee have taken some independent decisions which went against the interest of Gazprom.

\subsubsection{Oil sector}

Ensure that the taxation and the regulatory regime yield an adequate responsiveness of exploration and production to oil price fluctuations. (2009)

Reduce barriers to foreign participation in the Russian oil and gas sector in order to bring foreign know-how to bear on the efficient development of new fields in inaccessible parts of the country. (2009)

Broadly harmonise taxation of gas and oil, with the elimination of export taxes. (2009)
System of export duties for oil industry "60-66" introduced in October 2011 promoted investment in exploration and production.

Currently, according to the amended legislation the threshold of foreign capital participation in strategic companies in the oil and gas industries increased from $10 \%$ to $25 \%$.

The harmonization of oil and gas taxation has partly happened, and there is an important reform effort ongoing to support the development of the next generation of resources, but the export tax is far from being eliminated - it still represents $30 \%$ of the gas export value and $60 \%$ for crude oil. As from 2014, according to a newly adopted tax regulation, the severance tax on gas will be changing form the fixed rates to the calculation based on a formula that takes into account geographical and geological characteristics of the fields. Yet there is a difference in taxation levels of Gazprom (stronger taxation) and non-Gazprom companies.

The budget draft for 2014-16 foresees reduction of export duties on oil and light oil products, while increasing severance tax on gas and oil with exceptions including hard to recover resources.

\subsection{Environment and energy efficiency}

\subsubsection{Environment protection}

Expand the use of fiscal instruments to improve environmental outcomes. (2009)

Introduce mechanisms (such as a carbon tax or a cap-and-trade system for GHG emissions) to price in the negative externalities of fossil-fuel-based energy. (2011)

Expand the use of green taxes to reduce energy consumption and discourage environmentally harmful activities. (2011)
Russia has been discussing reforms of the tax system on pollution for some time already and in 2013 pollution charges were raised by several times and in some cases by ten folds.

Following the Government Regulation of 17 January 2013 MED with participation of European Bank for Reconstruction and Development and "Business Russia" is preparing proposals for establishing National system of carbon regulation for 2014-20.

Currently there are no green taxes in place, however Russia authorities are discussing its implementation. 


\section{Recommendations in past Surveys (Survey year)}

\subsubsection{Increasing energy efficiency}

Phase out all subsidies for domestic energy use. Work towards a system in which regulated tariffs are set to achieve economic efficiency, while low-income households are assisted via the tax and benefit system. (2011)

Speed up the installation of meters for all forms of energy and water, including via the use of financial incentives. (2011)

Ensure that all energy consumers are offered multilevel tariffs differing by time of day, and introduce lower tariffs for interruptible service. (2011)

Use cost-benefit analysis to evaluate and monitor different approaches and projects, including all social costs and benefits, such as the benefits of avoided GHG emissions and other environmental impacts. (2011)

Require that government agencies involved in implementing the energy efficiency strategy work with Rosstat and energy efficiency experts to arrive at a streamlined list of high-priority indicators of energy efficiency. (2011)

Create specific policy packages to help small and medium-sized enterprises improve their energy efficiency. (2011)

At least until energy prices adequately reflect marginal social costs, implement measures in the transport sector, such as mandatory fuel efficiency standards for cars and trucks. (2011) development of traffic management and road infrastructure. A congestion charge for Moscow should also be considered, with the application of reduced charge rates for hybrids and electric cars from the charge. (2011)

Reinforce policies to improve industrial energy efficiency, such as removing obstacles to the development of energy service companies specialising in such areas as lighting systems, electric motors, and steam systems. (2011)

\section{Actions taken since October 2011}

Regulated tariffs for final household consumers have been gradually increasing towards cost recovery, but in the wake of the economic slowdown, domestic prices of utilities, including electricity and gas, may be either frozen or increased more slowly than inflation in the next three years. A new government decision foresees an increase in prices above newly introduced consumption norms for households.

Although energy consumption meters are legally required, only $40 \%$ of residential houses and $20-25 \%$ of apartments have them installed so far. Non-metered consumption is to be subject to higher tariffs starting in 2015.

Tariffs started to be differentiated depending by the volume of consumption on 1 February 2013. Tariff differentiated by time of day was made available also to households in summer 2013.

Currently there is no cost-benefit analysis in place.

No known actions taken since October 2011.

The main policy instruments currently include tax credits, state subsidies and loan guarantees for efficiency improvement projects.

More ambitious mandatory fuel efficiency standards for cars and trucks have been introduced: in January 2013, Russia decided to ban EURO-3 fuels as from 31 December 2014 and Euro 4 standards as from 21 December 2015. Proposals of tax changes encouraging the use of natural gas in transport are being discussed, but have not yet been adopted.

Russia has been moving to tighter emission standards for its refined products and has been starting to upgrade and modernize its refineries accordingly.

City authorities try to tackle the problem by introducing dedicated lanes for buses, prohibition of heavy vehicle traffic and strict parking policies, but these measures are usually uncoordinated and not supported by appropriate economic incentives. Proposal to introduce congestion charges met strong resistance so far.

Initial steps have been made in promoting industrial energy efficiency through mandatory audits and reporting for large industrial energy consumers and establishing a scheme for benefits for investments in energy efficient equipment.

Newly adopted legislation addresses some but not all legal obstacles to the development of energy service companies.

The large scale certification system (energy passports) requires mandatory energy audits in all organisations with federal or municipal involvement. 


\section{Recommendations in past Surveys (Survey year)}

Given that building owners may not always have the right incentives to upgrade energy efficiency, develop instruments to mobilise financing for the renovation of the housing stock and speed up the rate of renovation is needed. (2011)

\section{Actions taken since October 2011}

The Housing and Public Utilities Fund has recently become responsible for accelerating housing renovation, while public financial support for the construction of energy efficient housing is still under discussion. Newly adopted legislation addresses some obstacles, but the rights of the contractual partners are still not defined clearly enough.

Work is on-going in developing new building energy codes. Russia is moving towards alignment with some European Union requirements in terms of standards and labels for a number of appliances.

\section{Fiscal policy}

\subsection{Fiscal rules and budgetary institutions}

Restore a rule governing management of oil and gas revenues and limiting the non-oil deficit, along with a well-defined escape clause regarding the circumstances in which the rule can be breached. (2011)

Supplement the non-oil deficit limit by a rule restricting the annual increase in total expenditure in real terms to some ceiling. (2011)

Develop the necessary expertise on the cyclical adjustment of non-oil revenues. Publish more detailed information on the underlying fiscal position, highlighting uncertainties. (2011)

Set up an independent fiscal council to perform a number of advisory tasks such as providing estimates of short-term macroeconomic variables and trend growth. An independent panel of experts can also help build expertise on the cyclical adjustment of nonoil revenues. (2011)
Budget rule, adopted in 2012, severely limits federal expenditures based on bench-mark oil price. Calculation of this price as an average value over a long period does not allow its skyrocketing and thus limiting the growth of expenditures.

No restrictions on expenditure growth were introduced to supplement the new fiscal deficit rule.

No known actions taken since October 2011.

The advisory council with representatives of independent organisations was created in 2012 to provide assessments and recommendation on draft federal programs prepared by the Ministry of Finance. Results of its work is made publicly available on the ministerial website.

\subsection{Tax policy}

Establish a tighter link between exhaustible natural resource taxation and economic rents, such as by applying the mineral extraction tax on a project basis, taking into account the cost structures in each field. (2009)

Harmonise tax rates to achieve a better balance between the taxation of economic rents from oil and that from the extraction of other non-renewable natural resources, including natural gas. (2009)

In the context of an overall reform of oil and gas taxation, eliminate export taxes on oil and gas. (2009)

in

A system of tax reliefs and exemptions for offshore and Far
East fields containing hydrocarbons essential for boosting
production in the remote regions was approved to support
current production and unlock new reserves. Tax reliefs were
also adopted for hard to recover oil resources.

The harmonization of oil and gas taxation has partly happened, and there is an important reform effort ongoing to support the development of the next generation of resources, but the export tax is far from being eliminated - it still represents $50 \%$ of the gas export value and even more for oil.

The State Duma Committee on Budget and Taxes introduced in September 2013 amendments increasing severance tax on oil and reducing marginal rate of oil export duty since 1 January 2014. Export duty on gas increased in November 2013.

Explore ways of reducing the comparatively high tax wedge. (2009)
The single rate reduced from $34 \%$ to $30 \%$ in 2012 , that is still higher than $26 \%$ in 2011 . The lowered rates of social insurance contributions were made available to some types of business and non-profit organisations. 


\section{Recommendations in past Surveys (Survey year)} providing for somewhat more progressivity in the latter in order to improve both economic efficiency and equity. (2009)

Explore the scope for expanding the use of property taxes, while further reducing corporate profit taxes and if possible social security contributions over time. (2009)

Expand the use of green taxes. (2011)

Consider increasing taxes on alcohol and tobacco products. (2011)
Rebalance corporate and personal income taxes,

\section{Actions taken since October 2011}

The Federal Law No. 214-FZ of 23 July 2013 established the use of multiplying factors to the rates of vehicle tax on expensive cars and there are plans to introduce progressive real estate taxation.

Key Tax Policy trends for 2013-15 adopted in April 2012 by Russian government included introduction of real estate tax.

Currently here are no green taxes in place, however Russia authorities are discussing its implementation.

President signed in 2013 the law on amendments to the Tax Code that increased excise duties rates on the alcohol and tobacco starting from 1 January 2014. The amendments increased the rates of excise duties on petrol, alcohol and tobacco products.

Excise tax rates will indexed according to the "Concept on combating tobacco consumption for 2010-15", which is planning to increase minimum specific rate of excise duty on cigarettes by $42 \%$ in 2014 compared to 2013 and in 2015-16 by 20 and $28 \%$, respectively.

Excise duty on the strong alcohol would be gradually increasing from RUB 400 per litre now to RUB 660 in 2016. The same situation will happen in the market of the light alcohol (increase from RUB 320 to RUB 550 per litre).

Improve the administration of VAT (in particular to address the problem of slow refunds), but refrain from cutting average VAT rates. Ensure that any harmonisation of the existing high and low rates is at least revenue neutral. (2009)

Address weaknesses in the tax and regional funding regimes to break the dependence of regional governments on a limited number of local firms for revenue raising. (2009)
No known actions taken since October 2011 given the requirement in place to refund VAT within 12 working days after tax audit.

\section{Monetary policy}

Clearly spell out price stability as the primary objective of monetary policy by amending the Central Bank Law. (2009, 2011)

The time horizon over which the objective should be achieved should also be specified. (2011)
According to the Federal Law No. 251-FZ of 23 July 2013 "On the Central Bank (of Russia)" included one more articles Article No. 34.1 which defines the main objective of monetary policy the Bank of Russia is the protection and stability of the ruble by maintaining price stability.

The time horizon is set by the "Guidelines for the United Governmental Monetary Policy". The main goal of monetary policy is currently stated in terms of end-of-year inflation declining from $5-6 \%$ in 2013 to $5 \%$ in $2014,4.5 \%$ in 2015 and $4 \%$ in 2016 . The transition to inflation targeting is supposed to be completed in 2015 and CBR prepared an action plan for the transition to the new regime and is working on its implementation. $^{2}$

2. At the moment of publication of this working paper Central Bank of Russia announced that" in case the imposed trade restrictions remain effective, as announced, for a period of one year, and in the absence of new negative factors, consumer price growth will decline to $4 \%$ in 2017 with no significant slowdown of the economy" (http://www.cbr.ru/Eng/today/publications_reports/on_15-eng.pdf). 
Recommendations in past Surveys (Survey year)

Foreign exchange interventions should be conducted only to the extent that they are consistent with the primary objective of price stability. $(2009,2011)$

\section{Actions taken since October 2011}

At the end of 2011 and in 2012, the Bank of Russia took steps to increase exchange rate flexibility, expanding the boundaries of the floating operating range of fluctuations in the currency basket and reducing the amount of foreign exchange intervention, the achievement of which leads to a shift of the operational boundaries of the interval.

Consider establishing a Monetary Policy Committee No known actions taken since October 2011. with a mandate to set policy rates. (2011)

Designate one or two policy rates as the main According to the action plan for the transition to inflation instrument(s) of monetary policy. (2011) targeting the Bank of Russia has developed a set of proposals on interest rate policy, including the choice of key interest rates.

\section{Publish regular information about inflation} expectations. Consider developing a market for inflation-linked bonds. (2011)

Hold press conferences following policy meetings and publish minutes of the meetings and/or voting records. $(2009,2011)$
In 2013, CBR started publishing surveys of population inflation expectations on its website.

In order to widely inform the public about monetary policy questions press-releases on the results of meetings of CBR Board of Directors are prepared and posted on the official website of the Bank of Russia. These documents explain the decisions taken, as well as provide a detailed analysis of the situation in the economy and the financial markets.

\section{BIBLIOGRAPHY}

Vaziakova, Y., G. Barnard and T. Lysenko (2011), "Russia: Progress in Structural Reform and Framework Conditions", OECD Economics Department Working Papers, No. 920, OECD Publishing, http://dx.doi.org/10.1787/5kg0k6zsbjbven. 
ECO/WKP(2015)70

\section{LIST OF ECONOMIC SURVEYS OF RUSSIA}

Economic Survey of the Russian Federation, 2013

Improving the business climate and transport infrastructure

Boosting productivity: Skills, education and innovation

Economic Survey of the Russian Federation, 2011

Modernisation of the Russian economy

Improving the business climate

Strengthening the fiscal framework to enhance resilience to external shocks and safeguard sustainability

Moving to a new framework for monetary policy

Increasing energy efficiency as a means to achieve greener growth

Economic Survey of the Russian Federation, 2009

Stabilisation and renewed growth: key challenges

Ensuring growth-friendly fiscal policy in both the short and the long term

Making exchange rate policy more flexible and monetary policy more effective

Making the banking sector more efficient and resilient

Improving regulation in Russia's goods and services markets

Economic Survey of the Russian Federation, 2006

Sustaining growth in the Russian Federation: key challenges

Ensuring sound macroeconomic management

Improving the quality of public administration

Raising the effectiveness of innovation policy

Reforming healthcare

Economic Survey of the Russian Federation, 2004

Sustaining growth

Industrial competitiveness

Natural gas

Power sector restructuring

Banking reform

Economic Survey of the Russian Federation, 2002

Economic overview

Small business and entrepreneurship

Gas and electricity: regulation and reform

Fiscal federalist relations: recent trends and prospects

Economic Survey of the Russian Federation, 2000

Macroeconomic overview

Demonetisation: the causes and policy implications

Fiscal federalism

Economic Survey of the Russian Federation, 1997

Macroeconomic performance, policies and prospects

Commercial banks

Enterprises

Economic Survey of the Russian Federation, 1995

Structural change and recent economic developments

Economic policy and policy-making

Some regional aspects

The development of markets: privatisation, corporate governance, competition and enterprise behaviour Labour market mobility and flexibility

Living standards and social protection 